DOI 10.2478/v10122-011-0008-3

\title{
A. DOLGOPOLSKY'S NOSTRATIC DICTIONARY AND AFRO-ASIATIC (SEMITO-HAMITIC)
}

\author{
GÁBOR TAKÁCS
}

\begin{abstract}
Gábor Takács. A. Dolgopolsky's Nostratic Dictionary and Afro-Asiatic (Semito-Hamitic). Lingua Posnaniensis, vol. LIII (1)/2011. The Poznań Society for the Advancement of the Arts and Sciences. PL ISSN 0079-4740, ISBN 978-83-7654-140-2, pp. 109-119.
\end{abstract}

The monumental comparative dictionary by Aharon Dolgopolsky (Prof. emer. of the University of Haifa), long awaited by many specialists interested in the long-range comparison of language families, is here at last, available online since spring 2008. ${ }^{1}$ What we have here is a life's work completing more than fifty years' research. The first online publication will soon be followed by a second revised edition. The present reviewer had the privilege in Haifa in December 2008 to be able to assist the author in reviewing the etymological entries with initial $* m$-.

The author is the internationally widely known doyen of this domain, which he established still in Moscow in the early 1960s together with the late Vladislav Illič-Svityč (1934-1966). Both of them were working initially and basically in the field of Indo-European comparative linguistics. Illič-Svityč was an expert on Balto-Slavonic accentology, while Dolgopolsky started his careeer as a researcher of Romance philology. But soon, both of them had become familiar with the results of Semito-Hamitic (recently called Afro-Asiatic after Greenberg), Kartvelian, Dravidian, Uralic, and Altaic historical linguistics. This had led them to a conviction, that has arisen independently in them, on the relationship of the six so-called Nostratic language families enumerated above (including Indo-European). Both scholars had naturally realized that Afro-Asiatic has the least elaborated and reliable phonological and lexical reconstruction ${ }^{2}$, whereas the proto-languages of the other five families had been uncomparably more clearly and coherently described or, at least (in the case of Altaic), approached. Not accidentally had both Moscovite scholars got to reconstructing two most problematic branches of Afro-Asiatic: Illič-Svityč chose Chadic ${ }^{3}$ and Dolgopolsky focused on Cushito-Omotic, where his fruitful research had yielded a number of fundamental publications ${ }^{4}$ until the end of his career in Moscow $(1976)^{5}$, where he left behind an informal

1 Edited by the MacDonald Institute of Archaeological Research (http://www.dspace.cam.ac.uk/handle/1810/196512). Some paper copies have also been released, but in a very limited tirage. It is here that I wish to thank Mrs. Zsuzsa Jancsó, the charming secretary (Oriental Dept., Institute of Linguistics, Hungary) for her unselfish help with the paper version of the Dictionary.

2 The unfortunate retardation of comparative Afro-Asiatic studies (as compared to other language families) has been due to all too numerous reasons that could be studied here.

3 For the reason of his tragical and premature end, Illič-Svityč had only the opportunity to publish but one pilot study on the reconstruction of Chadic lexical roots with initial labials (1966).

4 Cf. Dolgopolsky 1966 (proto-Cushito-Omotic lexical roots with initial labials and dental stops), 1972 (initial velar stops), 1973 (proto-Cushitic lexicon).

5 In September 1976, Dolgopolsky completed his aliyah. Since then, he has been lecturing at the Hebrew Language (Lashon Ivrit) Dept. of the Haifa University until his most recent retirement. 
school of comparative linguistics with talanted promising pupils like Sergej Starostin (Old Chinese, Altaic, North Caucasian), Evgenij Helimskij (Uralic), and Olga Stolbova (Chadic). Dolgopolsky's pioneering Comparative-Historical Phonology of Cushitic Languages (Сравнительноисторический словарь кушитских языков) from 1973 has been very frequently quoted even in Western works in spite of its being published in Russian. After 1976 in Haifa, Dolgopolsky has continued - beside Nostratic studies in general - first of all his comparative Afro-Asiatic research and publication activity devoted primarily to clarifying the regular consonant correspondences among the Afro-Asiatic branches ${ }^{6}$, which signifies where the priority task still lies in Nostratic. All these results have long raised Dolgopolsky - beside the late Igor' D'jakonov (1915-1999) of Leningrad (St. Petersbug) - to the rank of the highest authority in comparative-historical AfroAsiatic linguistics of recent times. This is why I devoted in 2008 a Semito-Hamitic (Afro-Asiatic) Festschrift in his honour. ${ }^{7}$

Prof. Dolgopolsky's profound knowlegde of the lexical stocks involved and of the etymological problems in all language families examined by him can only be admired. My present paper cannot be a review stricto sensu of this gigantic accumulation and analysis of many thousands of pieces of linguistic data, let alone the allotted very minimal space. What I regard as most effective under the circumstances is to investigate at least through a few sample entries chosen at random how this magnificent etymological dictionary uses lexical data of the most obscure and scientifically neglected language family, namely Afro-Asiatic. Elsewhere, it might have been probably substantially easier and smoother to extract etymological information from the domains of other language families by far better equipped with reliable etymological lexicons, most of which can be safely regarded as standard tools. If we look at how autonomously Dolgopolsky handles e.g. Indo-European etymologies, we can deduce that he is much farther off than just quoting the relevant etymological sources even in these well-equipped domains.

Unfortunately, the objective circumstances are many times less favorable in the case of Proto-AfroAsiatic, presumably the oldest one of all the known language families ${ }^{8}$, the parental language of Akkadian, Hebrew, Arabic, Egyptian etc., where we until now simply lack a comprehensive and high-quality comparative lexicon and a reliable lexical reconstruction. ${ }^{9}$ This is why partial results here are at the mo-

6 Cf. Dolgopolsky 1982 (the origin of intervocalic $*-\gamma$ - in the Suroid languages, West Chadic subbranch), 1983 (Semitic and East Cushitic), 1987 (South Cushitic lateral consonants compared to Semitic and East Cushitic), 1988 (word-initial laryngeals in Semitic and East Cushitic), 1989 (lateral obstruents in Hamito-Semitic), 1990 (Chadic correspondences of Semitic *s) 1994 (the Afro-Asiatic origin of some Semitic names of body parts), 1994 (paper presented at the 3rd World Archaeological Congress in New Delhi in Dec. 1994 on the external relations of Afro-Asiatic), 1994 (paper presented at the 6th International Hamito-Semitic Congress in Moscow in April 1994 on some new Afro-Asiatic etymologies), 1999 (from Proto-Semitic to Hebrew with a section devoted to the Afro-Asiatic background of the Hebrew lexicon).

Takács, G. (ed.): Semito-Hamitic (Afro-Asiatic) Festschrift for A.B. Dolgopolsky and H. JungraithMAYR. Berlin, 2008., Dietrich Reimer Verlag. On pp. Vii-viii, I have published my subjective recollection on both jubilants. In December 2008, during my visit to him at his Haifa home, I have recorded his own recollections (in Russian) on his enormous life which I plan to publish elsewhere (in English translation).

8 The split-up of the common Afro-Asiatic proto-language (starting with the separation of Cushito-Omotic from the rest) has been estimated by Militarev with the help of glottochronological methods to have taken place around the 11th or 10th millennia B.C. (see Mlt. 1983, 104-106; 1984, 9-10; Mlt.-Snr. 1984, 35; Djk. 1988, 23-25, 33, fn. 15; Mlt.PejRos-Š́niRel'MAN 1988; Mlt. 1989, 128). Of course, this tentative result requires further verification.

9 The first such attempt, viz. Marcel Cohen's famous and epoch-making "Essai comparatif ..." from 1947 has long become fully outdated and only very few entries can be used. Then a long gap followed until D'jakonov and his Moscow team started to publish their Comparative-historical Dictionary of Afrasian Languages (Сравнительно-исторический словарь афразийских языков, abbreviated as SISAJa I-III, in Russian), which, however had to remain unfinished after the publication of but three thin fascicles (1981: initial labial stops, 1982: initial dental stops, 1986: initial sibilants + labial stops as second radicals). The Hamito-Semitic Etymological Dictionary (HSED) by OReL and STOLBova from 1995 reflects basically the conception and many results of the Moscow team, but suffers from a number of fundamental methodological problems (cf. TAKÁCS 1997). The comparative lexicon by EHRET from 1995 contains unfortunately more problems and errors than solutions and is hardly 
ment much more important than the very uncertain comparative dictionaries. Ever since I have known Dolgopolsky's Russian and English articles on Nostratic in general, I have eagerly observed how these - as a "side-effect" - contribute to our scanty knowledge about Afro-Asiatic lexical correspondences. To my mind, the language family of all Nostratic families where the quantitative progress in the inner comparative study of the lexicon has gained most from Illič-Svityč's and Dolgopolsky's Nostratic work is just the still obscure domain of Afro-Asiatic etymology, and vice versa: I have no doubt that modern Afro-Asiatic comparative research has received the strongest impulse from Nostratic linguistics in Moscow, suffice it to refer - beside Illič-Svityč and Dolgopolsky - to Stolbova, Militarev, and Blažek (who also belongs to the Moscow school), the most productive authors of comparative Afro-Asiatic in the recent decades.

The Nostratic Dictionary testifies to Dolgopolsky's significant research results contributing to AfroAsiatic etymology, which is until now hindered by a number of objective circumstances: (1) even we ourselves in the Moscow school only have a general working hypothesis on the basic consonantal correspondences (esp. in the relationship of Proto-Semitic, Egyptian, and Proto-Berber), which have not yet been satisfactorily elaborated and thoroughly tested in all details (esp. in the least explored Omotic and Chadic daughter languages). (2) Secondly, it has always been - almost irrespectively of the individual authors (albeit in different degrees) - difficult in our etymological research, especially in the case of Semitic and Egyptian, to keep a balance between the philological background of our comparanda and their external parallels. Dolgopolsky has worked carefully in order to minimize these unavoidable negative effects. My comments to the following etymological entries that were selected at random mostly carry additional data, new cognates, which signifies the still unexploited immense treasure and possibilities in our domain. May this discussion gain new friends for Nostratic studies and Afro-Asiatic etymology!

Gábor Takács, Székesfehérvár 8000, Semmelweis u. 19, Hungary, gabtak@mail.datatrans.hu

Nst. *IEga "1. to lie (down), 2. lay, put" [Dlg. 2008, 1195f, \#1265] = *LVga “лежать” [IS 1976, §271; also 1965, 346] (Krt., IE, Ur., WCh.). The AA family is represented here by WCh. parallels that may be sorted in two groups that may be mutually unrelated: (1) Sura $l \grave{\varepsilon}$ "setzen" [Jng.] etc. (neither reflecting *-g-) vs. (2) Mangas ligè "to wait" [Csp.] etc. (semantically uncertain). Instead, good cognates appear in Eg. $3 g$ [reg. <*lg] "pflanzen" (PT 513d, Wb I 22, 8) = "pflanzen, wachsen lassen, aufsprießen lassen" (ÄWb I 21) ||| CCh.: Bachama laga "to plant" [Crn. 1975, 465], which are semantically especially close to Krt. *lag- *lg- "1. to put $\rightarrow$ 2. to plant” [KLIMOV 1964: 118-119].

Nst. * LikV "to be ill, suffer disaster" [Dlg. 2008, 1200f, \#1273] (IE, AA: Agaw, Alt.): the

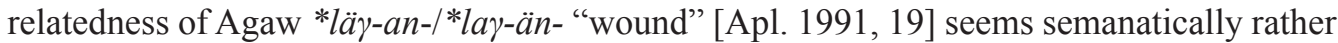
unlikely. ${ }^{10}$ All the more, since its further AA cognates ${ }^{11}$ point to a quite different basic sense (i.e., "wound") of the underlying AA root $* l-k$. The same is the case with Geez $l \bar{a} k^{w} \bar{a}$, lak $k^{w} \bar{a}$, $l a k^{w} \bar{e}$ "altercation, strife, conflict", tala $k^{w} a y a$ "to quarrel with another, dispute, reprimand" [Lsl. 1987, 314], which belongs to yet another AA root. ${ }^{12}$ On the other hand, Nst. *LikV-es-

to be used. I have started to publish my series Lexica Afroasiatica with new etymologies in 2002 (the first issue was, besides, dedicated for the 70th birthday of Prof. Dolgopolsky).

${ }^{10}$ The Agaw stem appears at the first glance to be identical with Eg. * $n k$ "to wound" (its derivation from *lk is in theory possible) > nkn "verletzen, beschädigen" (PT, Wb II 346, 8), nk.t "blessure" (CT, AL 78.2258; AECT II 100, spell 468, n. 25), nknk.t nkk.t "das verletzte Auge" (BD, Wb II 347, 6 \& 9), but this Eg. root has been usually combined with Sem. * $n k y$ "to hurt" [Bmh.], which points to an initial AA * $n$-. For the Eg.-Sem. comparison see EMBER 1913, 115, \#47; GÄSW \#55; Bmh. 1986, 254.

${ }_{11}$ Sem.: Dathina $l k k$ "donner un coup de poing à la nuque", $l k l k$ "frapper du poing à plusieurs reprises", lky: ?alkā "heurter, blesser" [GD 2643] || LECu. *log- "wound" [GT] || Ch. *l-k "wound" [St1.]: Jimbin lakwa "tattoo" [Skn.] || CCh.: Mada mlak "plaie" [Brt.] | Hide luku "plaie" [Egc. 1971, 214] (Ch.: Stl. 2005, 71, \#212).

${ }^{12}$ Cf. AA *l-k "to quarrel, 2. Fight" [GT] > SBrb.: EWlmd.-Ayr ə-lək "1. disputer avec au cours d'un juge- 
pecially in the light of Albanian lig (adj.) "evil, wicked, bad, sick" - may nevertheless have semantically likely AA reflexes, cf. Eg. *lklk (or *lqlq?) > (B) $\lambda$ o $\gamma \kappa \lambda d \alpha$ “böse" (KHW

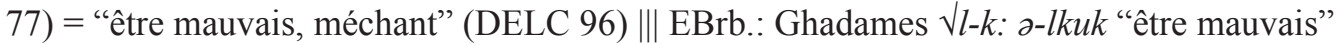
[LANFRY 1973, 180, \#890].

Nst. *Luka "to bend" [Dlg. 2008, 1201f, \#1274] = *Luka [Dlg. 1991 MS, \#883] (Brb., IE). The quoted Berber reflexes, viz. NBrb.: Mzab llaklak "être ébranlé, bouger, être disloqué, plier sous le poids" [Dlh. 1984, 105] || SBrb.: Ahaggar lak-ət "tourner (changer de direction), décrire une courbe, être courbé" [Fcd. 1951-1952, 1028-1029], have a nice cognate in Eg. $3 k$ [reg. < *lk] "beugen $(\approx h$ hb $)$ " (MK, Wb I 22, 3) = "gebogen sein" (ÄWb II 45). On the other hand, some of the quoted cognates deriving from Altaic *lak' $u$ "to bend, hang" [Sts.], namely Tunguz *loka- "to hang down (tr.)" [Dlg.], are perhaps better to be affiliated with AA *l-k "to hang" [GT] > SBrb.: Ayr $a$-lok"1. être suspendu, 2. se pendre (se suicider en se pendant)" [PAM 2003, 470] ||| WCh.: Dera lóowè [Nwm.: reg. < *lóokè] "to hang sg. over shoulder" [Nwm. 1974, 129], Kwami lògáy "aufhängen" [LEGER 1992, 27] || (?) CCh. *l-g "to hang" [JS 1981, 130D $]$ > (?) Logone hi léga "aufhängen" [Lks. 1936, 97] ${ }^{13}||$ ECh.: EDangla àlgìyē "hängen” [Ebs. 1979, 146; 1987, 84].

Nst. *Lo[?]ika "cutting instrument" [Dlg. 2008, 1206, \#1278] (IE, Alt., Brb.): the quoted Brb. parallels, namely EBrb.: Ghadames tê-laq- $t$ "poignard de bras" [Lnf. 1973, \#912] || SBrb.: Ahaggar tē-laq, pl. te-ly-īn "poignard" [Fcd. 1951-1952, 1109], Ghat te-laq, pl. te$l \gamma$-en "small knife" [Alj. 1980, 111] etc., suggest AA *l-k (or *l-h) as Dolgopolsky correctly stated. But whether the glottalization of AA *- $k$ was really due to a contraction of Nst. *- ?- $k$ remains uncertain, since a possible AA cognate (not mentioned in the Nostratic Dictionary), viz. Eg. 3qh [reg. < *lkh] "Kriegsbeil" (XVIII., Wb I 22, 1), if correctly compared, may probably modify the AA reconstruction to $* l-k-h$ (and, henceforth, the AA cognates either do not belong under this Nst. root or it should be significantly modified: *Lohika $\sim$ *Lokiha).

Nst. *La Ka "leg” [Dlg. 2008, 1209f, \#1282a] = *t[a] Ка “нога" [IS 1976, \#255] (AA, IE, ?Ur., ?Alt.): the AA parallels seem to fall in two groups: (1) Brb. *lV " (part of the) leg" [Dlg.] || SCu.: Dahalo lúka "leg from thigh to knee" [EEN 1989, 42; Tosco 1991, 142]

ment, 2. se charger de juger, 3. lutter contre" [PAM 2003, 349] ||| ECu.: Dobase lāk- "bekämpfen, sich zur Wehr setzen" [AMS 1980, 171] ||| WCh.: Angas-Sura *lyak (Suroid, Goemay) *lyok (Angas), hence *lēk $\rightarrow$ *lek "1. to fight, 2. war" [GT] = *l[i]ak "to fight" [Dlg.]: Angas liok "to fight", leok "war" [OrmSBY 1914, 208-209, 314-315] = lääk leok "1. war, 2. to make war, fight, quarrel violently" [Flk. 1915, 232, 237] = leck (so, long

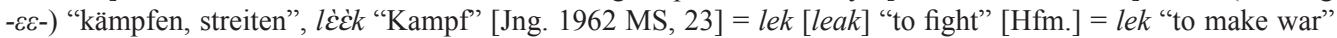
[ALC 1978, 15, 32, 37] = lēk lèk "to fight a fight" [Gcl. 1994, 109, 121], Sura lek "1. sich auflehnen, kämpfen" [Jng. 1963, 73] = lek "to fight" [Hfm.], Kofyar lek "to fight" [Ntg. 1967, 24] = liak "to fight" [Hfm.], Mushere lek "to fight, struggle" [Dkl. 1997 MS, 139], Chip liyək (so, -ə-) "war" [Krf.], Montol lek "1. to fight, 2. war" [Ftp. 1911, 216, 221], Goemay liak šal "to fight" [Srl. 1937, 126] = liak (šal) "to fight" [Hfm.] = lyak šal "to fight" [Hlw. 2000 MS, 21] (AS: Hfm. 1975, 21, \#137; Stl. 1987, 199, \#503; GT 2004, 238) || ECh.: Kera mẹ-láagà [nomen loci $m V$ - prefix] "belt of war" [PEARCE 1998-1999, 64]. An AA root variety with *-h- as $\mathrm{C}_{2}$ is attested in Sem.: OSA (Sabean) $\sqrt{ } l h y: l h[n] \sim$ var. $l[h y] n$ "dispute, quarrel" [SD 258], Ar. $l h w$ III "4. calomnier qqn." [BK II 981] III SBrb.: Ayr $u$-lay [Brb. * ${ }^{*}<\mathrm{AA} * h$ reg.] "1. lutte finale (corps à corps) dans les jeux de tulăge et de rəbəkrəbək, 2. Défaite" [PAM 2003, 460].

${ }_{13}$ The CCh. reflex is doubtful, since the CCh. proto-form was based by JS solely on the Logone form, which may have had a different origin, cf. Logone há "werfen" + léga "darauf" [Lks. 1936]. Buduma lki "aufheben" [Lks. 1939, 117] is little helpful as it may belong to an entirely different AA root. Note that EHRET $(1995,400$, \#816) combined the uncertain CCh. root with other untenable AA comparanda (q.v.). 


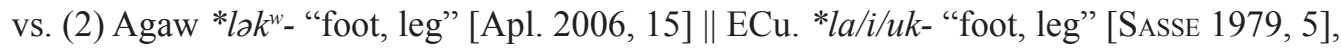
which suggest two PAA root varieties: $* l-k$ vs. $* l-k$, resp. The latter is probably also reflected by Eg. * $3 \underline{t}$ "foot, leg", a lost word that can be reconstructed from the MK phonetic value $3 \underline{t}$ of the leg hieroglyph (D56), cf. ÄWb II 47, 50.

Nst. *Lûka "to swallow" [Dlg. 2008, 1213f, \#1286] (AA, Krt., IE, Alt., Drv.): the AA reflexes quoted by Dolgopolsky can be divided into two groups: (1) AA *l-k vs. (2) AA *l-k-m. Some additions are possible to both sections: (1) Add Sem.: Sqt. dial. of Qalansiya líkalak

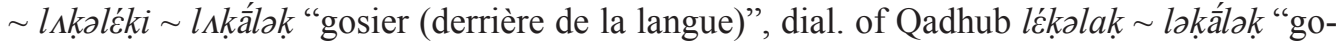
sier, arrière-bouche" [SSL 1991, 1465] ||| LECu.: Somali līq "schlucken, verschlingen” [Rn. 1902, 276] || SCu.: Dahalo laka "area under chin" [EHRET 1980, 328, \#76: LECu.; EEN 1989, 41] || Ch. *lak- "to swallow" [Stl. 1996] = *l-k "to eat hastingly and choke" [Stl. 2005] > WCh.: Hausa lákè "to rapidly eat up small, tasty amount of”, lákài-lákài "parasitic glutton" [Abr. 1962, 609] || ECh. *lak- "to swallow" [Stl.] (Ch.: Stl. 1996, 126; 2005, 72-73, \#215). (2) Here, add Sem. *ha-lkum- "fauces, Adam's apple” [SED I \#117; Mlt. 2005, 371, \#58; 2005, 587-588, \#58.1: body part prefix *ha-]. (3) There may have been a third AA root $* l-k-f$ (with a root extension *-f), cf. Ar. laqifa " 1 . avaler qqch. avec précipitation (celui qui a faim p.ex.)" [BK II 1015] || Eg. *nqf [reg. <*lkf], a lost word that can be reconstructed from the throat determinative of $n q f$ (cf. Wb II 344, 2; GHWb 436).

Nst. *lüHKa "to jump" [Dlg. 2008, 1217f, \#1290] (AA, IE, Ur., Alt.): the relatedness of Ar. $l q \rho$ "passer rapidement" [BK II 1015] is rather uncertain. The most reliable AA derivative mentioned in ND is WCh.: Ron *luk "to rise" [GT], cf. Bokkos luk"(auf)fliegen", luk fit "aufstehen", Fyer luk "aufstehen", Daffo-Butura luk "springen (auf und ab)", Sha lúgó "aufstehen (Distanz mit Richtung der Aktion auf Sprecher)" (Ron: Jng. 1970, 87, 144, 217, 286). The Ron root was alternatively combined by Orel and STOLBOva (1990, 81, \#61) with Ar. $h l q$ II "5. planer et tournoyer dans les airs (oiseau), 8. être au plsu haut du ciel (étoile)" [BK I 481], which, however, does not account for the Ar. $h-$. Although I also observed the regularity of Ron $* k<$ AA $* k$ (TAKÁCs 2000, 96-97), I would, nevertheless, not exclude the cognacy of Ron *luk with Eg. jtit [reg. < *lkk] "Verbum (vom fliegen o.ä. eines Vogels)" (PT, Wb I 151, 6) = “*(herab)fliehen” (GHWb 115; ÄWb I 240).

Nst. * $\boldsymbol{L} \boldsymbol{V} \boldsymbol{K} / \boldsymbol{V}] \boldsymbol{X} \boldsymbol{V} \sim$ * $\boldsymbol{L} \boldsymbol{V} \boldsymbol{X} / \boldsymbol{V}] \boldsymbol{K} \boldsymbol{a} / \boldsymbol{a} \boldsymbol{e}$ "to grasp, catch" [Dlg. 2008, 1220f, \#1294]: its only AA reflex mentioned in the ND, Sem. *lkh "to take" [Dlg.], is akin to Eg. $h 3 q$ [reg. < *hlk] "erbeuten, erobern" (MK, Wb III 32-33) = "to plunder, capture" (FD 163). For Eg.-Sem. see EMBer 1911, 88; 1917, 88, fn. 2; 1926, 302, fn. 10; 1930, \#3.c.4, \#20.a.6; Holma 1919, 40; LeXA 1938, 217; Vrg. 1945, 130,\#1.d.19; Chn. 1947, \#442.

Nst. *LiL $\boldsymbol{V}$ "water, sea" [Dlg. 2008, 1221f, \#1296] (AA, IE, ?Alt.): add LECu.: Oromo lol-ā "1. flood, 2. puddle", lola?a "flow (n.)" [Btm. 2000, 182], Borana Oromo loll-ā "puddle" [Strm. 1995, 205] | HECu. *lola ?a "flood, torrent" [Hds. 1989, 65, 417] || SCu.: (?) Ma'a loló "urine" [EHRET 1974 MS, 40] ||| NOm.: Kachama ma-lēl-o "river" [Sbr. 1994, 18]. Perhaps also Eg. $n n$ [if <*ll] "als Bezeichnung der Überschwemmung" (GR, Wb II 275, $14)$ = "inundation" (DELC 97)? These parallels speak against alternatively explaining Brb. *i-lil "sea" [GT] and Bed. lìl- "to be liquid" [Rpr. 1928, 86] from Nst. *llVyhV "to pour (water)" [Dlg.]. The reconstruction of Sem. *nīl- "large river, flood, watering" [Dlg. pace Vcl.] (based on Akk. + Ar.) and the derivation from *lil- (via assimilation) is uncertain, since 


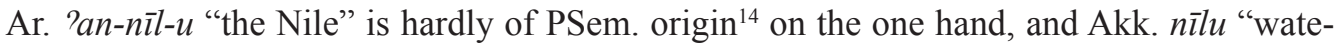
ring, flooding" [CAD n2, 234] has been explained from Sem. *nhl (AHW 694, 790), on the other hand.

Nst. *L/ẑilı/ĺV "reed, a water-plant” [Dlg. 2008, 1222, \#1297]: fairly certain AA reflexes shows up in Eg. nn.t [reg. < *ll-t] "eine Pflanze, aus der man Körbe macht: Binse (?)" (PT, Wb II 274, 10) = "Heleocharis palustris ( $\approx$ Scirpus palustris Linn.): jonc de marais ou scirpe des marais" (LORET 1932, 308-309), cf. the hieroglyph $n n$ depicting "two rushes with shoots" (Grd. 1927, 471, M22) = "aglet-headed rush, marsh club-rush (Sumpfbinse, gemeines Ried)" (Bonnier apud Loret 1.c.) = "rush with shoots" (FISCHER 1983, 34, M22) || WCh.: Kulere lùl "Gras, Stroh (zum Dachdecken)" [Jng. 1970, 353].

Nst. *lum $\boldsymbol{V}$ “magic, spell, fortune” [Dlg. 2008, 1222, \#1298] (Ur., Alt., Ar.): the only AA derivative of this Nst. root very correctly adduced by Dolgopolsky, namely Ar. lamam- "folie, obsession, commencement de la folie attribué à l'action des demons" [BK II 1022-3], can be complemented with new AA reflexes, cf. Eg. *lı́m > Cpt. (B) $\boldsymbol{\lambda}$ d $\boldsymbol{M}$ "Beschwörung" (KHW 515 pace BIFAO 45, 72, fn. 6) ||| ECh.: (???) Tumak là:m "tromper" [Cpr. 1975, 79] | Birgit làamí "ensorceler" [Jng. 2004, 356]. ${ }^{15}$ The relatedness of Sem.: Gurage: Muher, Masqan, Goggot, Soddo, Wolane lam etc. "charm, attractiveness" [Lsl.] is doubtful, since LESLAU (1979 III, 279) affiliated this form with Gurage: Selti läma etc. "to prosper" (ultimately $<$ Sem. $* \operatorname{lm}$ () arguing that the noun had the primary meaning of "something what is in a flourishing state, good condition".

\section{ABBREVIATIONS OF LANGUAGES}

Alt.: Altaic, (A): Ahmimic, AA: Afrasian (Afroasiatic, Semito-Hamitic), Amh.: Amhara/-ic, Ar.: Arabic, Aram.: Aramaic, AS: Angas-Sura, assim.: assimilation, (B): Bohairic, Bch.: Bauchi, Bed.: Bedawye, Brb.: Berber, C: Central, Ch.: Chadic, Cpt.: Coptic, CT: Coffin Texts, Cu.: Cushitic, Drv.: Dravidian, det.: determinative, dissim.: dissimilation, E: East, Eg.: Egyptian, ES: Ethio-Semitic, ESA: Epigraphic South Arabian, Eth.: Ethiopian, Eth.-Sem.: Ethio-Semitic Ethiopian Semitic, (F): Fayyumic, GR: Greco-Roman Period, Grg.: Gurage, GW: group-writing (or syllabic writing), Hbr.: Hebrew, Hrs.: Harsusi, IE: Indo-European, irreg.: irregular, Jbl.: Jibbali, Krt.: Kartvelian, Lat.: Latin, LP: Late Period, M: Middle, Mag.: Magical Texts, Med.: Medical Texts, MK: Middle Kingdom, MSA: Modern South Arabian, N: North (in compounds), NE: New Egyptian, NK: New Kingdom, O: Old, OK: Old Kingdom, Om.: Omotic, OSA: Old South Arabian, P: Proto-, poss.: possible, reg.: regular, PT: Pyramid Texts, S: South, (S): Sahidic, Sem.: Semitic, Shr.: Shahri, Sqt.: Soqotri, Syr.: Syriac, Tna.: Tigrinya, Ur.: Uralic, Ug.: Ugaritic, var.: variant, W: West, Wlm.: Tawllemmet.

\section{ABBREVIATIONS OF AUTHOR NAMES}

Abr.: Abraham, Alj.: Alojaly, AMS: Amborn \& Minkern \& Sasse, Apl.: Appleyard, BK: Biberstein de KazimiRski, Bmh.: Bomhard, Brt.: Barreteau, Btm.: Bitima, Chn.: Cohen, Crn.: Carnochan, Dbr.-Mnt.: Duibrine-Montgolfier, Dkl.: Diyakal, Dlg.: Dolgopolsky, Dlh.: Delheure, Ebs.: Ebobisse, EEN: Ehret \& Elderkin \& Nurse, Egc.: Eguchi, Ehr.: Ehret, Fcd.: Foucauld, Flk.: Foulkes, Ftp.: Fitzpatrick, Gcl.: Gochal, Grd.: Gardiner,

${ }^{14}$ On the origin of the name of the Nile diverse theories have been put forward, cf. most recently LufT 1992.

15 Any connection to Ar. lwm: lāma "blâmer, critiquer, reprendre qqn., lui adresser des reproches, blâmer qqn. d'avoir fait qqch." [BK II 1043] ||| NBrb. (from Ar.): Zayan \& Sgugu *lum > ľam "réprimander, sermonter" [Lbg. 1924, 563], Senhazha laum "réprimander qqn., lui faire des reproches" [Rns. 1932, 336] ||| ECh.: EDangla lòomiye "accuser" [Dbr.-Mnt. 1973, 190]? 
GT: Takács, Hds.: Hudson, Hfm.: Hoffmann, Hlw.: Hellwig, IS: Illič-Svityč, Jng.: Jungraithmayr, JS: Jungraithmayr \& Shimizu, Krf.: Kraft, Lks.: Lukas, Lnf.: Lanfry, Lsl.: Leslau, Mlt.: Militarev, Ntg.: Netting, Nwm.: Newman, OS: Orel \& Stolbova, PAM: Prasse \& Alojaly \& Mohamed, Rn.: Reinisch, Rns.: Renisio, Rpr.: Roper, Sbr.: Siebert, Skn.: Skinner, Srl.: Sirlinger, Ss.: Sasse, SSL: Simeone-Senelle \& Lonnet, Stl.: Stolbova, Strm.: Stroomer, Sts.: Starostin.

\section{LITERATURE}

Aвraham R.C. 1962. Dictionary of the Hausa Language. ${ }^{2}$ London: University of London Press.

Adler C., Ember A. (eds.). 1926. Oriental Studies Published in Commemoration of the Fortieth Anniversary (1883-1923) of Paul Haupt as the Director of the Oriental Seminary of the Johns Hopkins University. Baltimore: The Johns Hopkins University Press.

AECT $=$ FAuLKNER Raymond Oliver. 1973-1978. The Ancient Egyptian Coffin Texts. Vol. I-III. Warminster: Aris \& Phillips Ltd.

AHW $=$ SoDEN Wolfram von. 1965-1981. Akkadisches Handwörterbuch. Vol. I-III. Wiesbaden: Otto Harrassowitz.

AL I-III = Meeks D. (1977-1979). Année lexicographique. Égypte ancienne. Tome 1-3. 2ème édition. Paris 1998: Cybele.

ALC 1978 = Angas Language Committee (in Cooperation with Nigeria Bible Translation Trust). 1978. Shjk nkary kè shəktok mwa nḍ̂n Ngas. Ngas-Hausa-English Dictionary with Appendix Showing Some Features of Ngas Grammar. Jos, Nigeria: Nigeria Bible Translation Trust.

Alojaly Ghubeïd. 1980. Lexique touareg-français. Copenhague: Akademisk Forlag.

Amborn Hermann, Minker Günter, SASSE Hans-Jürgen. 1980. Das Dullay. Materialen zu einer ostkuschitischen Sprachgruppe. Berlin: Reimer Verlag.

Appleyard David. 1991. "The Vowel Systems of Agaw: Reconstruction and Historical Inferences." In: Proceedings of the Fifth International Hamito-Semitic Congress. Band II. Wien: Afro-Pub, 13-28.

ApPleYARD David. 2006. A Comparative Dictionary of the Agaw Languages. Köln: Rüdiger Köppe Verlag.

ÄWb I = HannIg Rainer. 2003. Ägyptisches Wörterbuch I. Altes Reich und Erste Zwischenzeit. Hannig-Lexica 4. Mainz am Rhein: Verlag Philipp von Zabern.

ÄWb II = HANNIG Rainer. 2006. Ägyptisches Wörterbuch II. Mittleres Reich und Zweite Zwischenzeit. I-II. Hannig-Lexica 5. Mainz am Rhein: Verlag Philipp von Zabern.

BibersteIn KaZImirski A. de. 1860. Dictionnaire arabe-français. Paris: Maisonneuve \& Co. Editeurs.

$\mathrm{BIFAO}=$ Bulletin de l'Institut Français d'Archéologie Orientale (Le Caire).

Bitima Tamene. 2000. A Dictionary of Oromo Technical Terms. Oromo-English. Köln: Rüdiger Köppe Verlag.

BomHard Allan R. 1986. "Common Indo-European/Afroasiatic Roots. Supplement 1." General Linguistics 26, 225-257.

Bynon J., Bynon Th. (eds.). 1975. Hamito-Semitica. The Hague: Mouton.

$\mathrm{CAD}=$ The Assyrian Dictionary of the Oriental Institute of the University of Chicago. Vol. 1-21. Glückstadt \& Chicago, Since 1956, J. J. Augustin, The Oriental Institute of the University of Chicago.

CARnochan Jack. 1975. "Bachama and Chadic.” In: Bynon \& BYnon 1975: 459-468.

CoHEN Marcel. 1947. Essai comparatif sur le vocabulaire et la phonétique du chamito-sémitique. Paris: Librairie Ancienne Honore Champion.

CT = Buck Adrian de. 1935-1961. The Egyptian Coffin Texts. Vol. I-VII. Chicago: The University of Chicago Press.

DELC $=$ VyCichl Werner. 1983. Dictionnaire étymologique de la langue copte. Leuven: Peeters.

Delheure Jean. 1984. Dictionnaire mozabite-français. Paris: Société d’Études Linguistiques et Anthropologique de France (SELAF).

DiAKonofF Igor' Mihajlovič. 1988. Afrasian Languages. Moscow: Nauka.

DiYakal Philibus. Mushere-English Dictionary. Collection of words carried out by Mr. Ph. I. D. started on September 10th, 1997 under the supervision of Herrmann Jungraithmayr (Univ. of Frankfurt). MS. 390 p.

DJibrine Bada Adoum Zaid, Montgolfier Paul de (etc.). Vocabulaire dangaléat. Kawo dayla. Place not indicated, around 1973 (deduced by G. Takács), publisher not indicated. 
DoLGOPOL'SKIJ Aron Borisovič. 1966. "Materialy po sravnitel'no-istoričeskoj fonetike kušitskih jazykov. Gubnye i dental'nye smyčnye v načal'nom položenii.” In: UsPENSKIJ 1966: 35-88.

DoLGOPOL'SKIJ Aron Borisovič. 1972. "Materialy po sravnitel'no-istoričeskoj fonetike kušitskih jazykov. Veljarnyj zvonkij v anlaute.” In: OHOTINA \& USPENSKiJ 1972: 197-216.

Dolgopol'SkiJ Aron Borisovič. 1973. Sravnitel'no-istoričeskaja fonetika kušitskih jazykov. Moskva: Nauka.

Dolgopolsky Aharon. 1982. "Chadic-Semitic-Cushitic: Epenthetic $-\gamma$ - in Sura in the Light of Hamito-Semitic Comparative Linguistics." In: JungraithmaYr 1982: 32-46.

Dolgopolsky Aharon. 1983. "Semitic and East Cushitic. Sound Correspondences and Cognate Sets." In: SegerT \& Bodrogligeti 1983: 123-142.

Dolgopolsky Aharon. 1987. "South Cushitic Lateral Consonants as Compared to Semitic and East Cushitic." In: JungraithMAYR \& MÜLleR 1987: 195-214.

Dolgopolsky Aharon. 1988. "Semitic and East Cushitic: Word-Initial Laryngeals.” In: TAdDESE 1988: 629-637.

Dolgopolsky Aharon. 1989. "On Lateral Obstruents in Hamito-Semitic.” In: SHEvoroshkin 1989: 99-103.

Dolgopolsky Aharon. 1990. "On Chadic Correspondences of Semitic *š.” In: MuKarovsky 1990: $213-$ 225.

Dolgopolsky Aharon. 1991. List of Nostratic Roots (5 December 1991). MS. Haifa, 36 p.

Dolgopolsky Aharon. 1994a. "Some Hamito-Semitic Names of Body Parts." In: GoldenBerg \& Raz 1994: 267-287.

Dolgopolsky Aharon. 1994b. Hamito-Semitic Etymologies. MS. Paper presented at the 6th International Hamito-Semitic Congress, Moscow, April 1994, 1 p.

Dolgopolsky Aharon. 1994c. External Relations of Afroasiatic. MS. Paper presented at the $3^{\text {rd }}$ World Archaeological Congress, New Delhi, December 1994, 5 p.

Dolgopolsky Aharon. 1999. From Proto-Semitic to Hebrew: Phonology. Etymological Approach in a Hamito-Semitic Perspective. Milano: CUSCUS.

Dolgopolsky Aharon. Nostratic Dictionary. Published by the MacDonald Institute of Archaeological Research in Cambridge at http://www.dspace.cam.ac.uk/handle/1810/196512.

EвoBisse Carl. 1979. Die Morphologie des Verbs im Ost-Dangaleat (Guera, Tschad). Berlin: Dietrich Reimer Verlag.

Eвовіsse Carl. 1987. Les verbaux du dangaléat de l'est (Guera, Tchad). Lexiques français-dangaléat et allemanddangaléat. Berlin: Dietrich Reimer Verlag.

Eguchi Paul Kazuhisa. 1971. "Matériaux pour servir à l'étude de la langue hidé. Vocabulaire." Kyoto University African Studies 6, 195-283.

EHRET Christopher. Ma'a - English Vocabulary. MS. Los Angeles, California, around 1974 (in Ehret 1980, 390 dated for 1966-1974), $82 \mathrm{p}$.

EHREт Christopher. 1980. The Historical Reconstruction of Southern Cushitic Phonology and Vocabulary. Berlin: Dietrich Reimer Verlag.

Ehret Christopher, Elderkin E.D., Nurse Derek. 1989. "Dahalo Lexis and Its Sources.” Afrikanistische Arbeitspapiere 18, 5-49.

EHRET Christopher. 1995. Reconstructing Proto-Afroasiatic (Proto-Afrasian). Vowels, Tone, Consonants, and Vocabulary. Berkeley-Los Angeles, California: University of California.

EMber Aaron. 1911. "Semito-Egyptian Sound Changes." ZÄS 49, 87-92.

Ember Aaron. 1913. "Kindred Semito-Egyptian Words. New Series.” ZÄS 51, 110-121.

Ember Aaron. 1917. "Kindred Semito-Egyptian Words (New Series)." Continued from Vol. 51, pp. 110-121. ZÄS $53,83-90$.

EMBer Aaron. 1926. "Partial Assimilation in Old Egyptian.” In: AdLer \& EMBER 1926: 300-312.

Ember Aaron. 1930. Egypto-Semitic Studies. Leipzig: The Alexander Cohut Memorial Foundation.

FD = FAULKNER Raymond Oliver. 1962. A Concise Dictionary of Middle Egyptian. Oxford: Clarendon Press.

Fischer Henry G. 1983. Ancient Egyptian Calligraphy. 2nd edition. New York: The Metropolitan Museum of Art.

FitzPatRICK J.F.J. 1910-1911. "Some Notes on the Kwolla District and Its Tribes." Journal of the Royal African Society 10, 16-52, 213--222.

Foucauld Charles de. 1951-1952. Dictionnaire touareg-français, dialecte de l'Ahaggar. Vol. I-IV. Paris: Imprimerie Nationale de France.

FoulKes H.D. 1915. Angass Manual. Grammar, Vocabulary. London: Kegan Paul, Trench, Trübner and Co. 
GARDINER Alan Henderson. 1927. Egyptian Grammar. ${ }^{1}$ Oxford: Clarendon Press.

GÄSW = CALICE Franz von. 1936. Grundlagen der ägyptisch-semitischen Wortvergleichung. Wien: Selbstverlag des Orientalischen Institutes der Universität Wien.

GD = LANDBERG Le Comte de. 1920, 1923, 1942. Glossaire datînois. Vol. I-III. Leiden: E.J. Brill.

GHWb = HANNIG Rainer. 1995. Grosses Handwörterbuch Ägyptisch-Deutsch (2800-950 v. Chr.). Mainz: Verlag Philipp von Zabern.

Gochal Golar. 1994. A Look at Shik Ngas. Jos: Jos University Press.

Goldenberg G., Raz Sh. (eds.). 1994. Semitic and Cushitic Studies. Wiesbaden: Otto Harrassowitz.

Hellwig Birgit. 2000. Goemai - English - Hausa Dictionary. MS. Draft. Printed out on 20 August 2000, 42 p.

Hoffmann Carl. 1975. Towards a Comparative Phonology of the Languages of the Angas-Goemai Group. MS. University of Ibadan, faculty seminar on 19 March 1975, $32 \mathrm{p}$.

Holma Harri. 1919. "Zur semitisch-hamitischen Sprachwissenschaft." Zeitschrift für Assyriologie 32, 34-47.

HSED = Orel Vladimir Émmanuilovič, STolbova Ol'ga Valer'evna. 1995. Hamito-Semitic Etymological Dictionary. Leiden: E. J. Brill.

Hudson Grover. 1989. Highland East Cushitic Dictionary. Hamburg: Buske.

ILLIČ-SviTYČ Vladislav Markovič. 1965. "Materialy k sravnitel'nomu slovarju nostratičeskih jazykov.” Étimologija, 321-373.

ILLIČ-SvitYČ Vladislav Markovič. 1966. “Iz istorii čadskogo konsonantizma. Labial’nye smyčnye.” In: UsPENSKIJ 1966: 9-34.

ILLIČ-SvitYČ Vladislav Markovič. 1976. Opyt sravnenija nostratičeskih jazykov (semitohamitskij, kartvel'skij, indoevropejskij, ural'skij, dravidijskij, altajskij). Sravnitel'nyj slovar' (l-ẑz). Ukazateli. Moskva: Nauka.

JungRAITHMAYR Herrmann. 1962. Wörterbuch der Angas-Sprache. MS.

JungraithmaYr Herrmann. 1963. "Die Sprache des Sura (Maghavul) in Nordnigerien." Afrika und Übersee 47, 8-89, 204-220.

JungratthmaYr Herrmann. 1970. Die Ron-Sprachen. Tschadohamitische Studien in Nordnigerien. Glückstadt: Verlag J. J. Augustin.

JungraithmaYr Herrmann (ed.). 1982. The Chad Languages in the Hamitosemitic-Nigritic Boder Area. Papers of the Marburg Symposion (1979, Berlin). Berlin: Dietrich Reimer Verlag, 32-46.

JungratthMAYR Herrmann. 2004. "Das Birgit, eine osttschadische Sprache - Vokabular und grammatische Notizen.” In: TAKÁCS 2004b: 342-371.

Jungraithmayr Herrmann, MülLer W.W. (eds.). 1987. Proceedings of the Fourth International Hamito-Semitic Congress. Amsterdam: John Benjamins.

Jungraithmay Herrmann, Shimizu Kiyoshi. 1981. Chadic Lexical Roots. Vol. II. Tentative Reconstruction, Grading and Distribution. Berlin: Verlag von Dietrich Reimer.

KaYE Alan S. (ed.). 1991. Semitic Studies in Honor of Wolf Leslau. Vol. II. Wiesbaden: Otto Harrassowitz, 14431487.

KHW $=$ WeSTENDORF Wolfhart. 1977. Koptisches Handwörterbuch. Heidelberg: Carl Winter Universitätsverlag.

KLIMov Giorgij A. 1964. Étimologičeskij slovar' kartvel'skih jazykov. Moskva: Izdatel'stvo Akademii Nauk SSSR.

KRAFT Charles H. 1981. Chadic Wordlists. I-III. Berlin: Dietrich Reimer Verlag.

LANFry J. 1973. Ghadames. II. Glossaire. Alger: Le Fichier Periodique.

LEGER Rudolf. 1992. "Sprachproblem aus dem Westtschadischen. Kupto- und Kwamitexte." Afrikanistische Arbeitspapiere 28, 5-32.

Leslau Wolf. 1979. Etymological Dictionary of Gurage (Ethiopic). Vol. III. Etymological Section. Wiesbaden: Otto Harrassowitz.

Leslau Wolf. 1987. Comparative Dictionary of Ge eez (Classical Ethiopic). Wiesbaden: Otto Harrassowitz.

LeXA František. 1938. "Développement de la langue ancienne égyptienne." Archiv Orientální 10, 215-272.

Luft Ulrich. 1992. "Nعĩðoç. Eine Anmerkung zur kulturellen Begegnung der Griechen mit den Ägyptern.” Studia Aegyptiaca 14, 403-410.

LuKAs Johannes. 1936. "Die Logone-Sprache im Zentralen Sudan." Abhandlungen für die Kunde des Morgenlandes 21(6).

LuKAs Johannes. 1939. "Die Sprache des Buduma in Zentralen Sudan." Abhandlungen für die Kunde des Morgenlandes 24(2).

Militarev Aleksandr Jur'evič. 1983. "Ob odnom obščeafrazijskom zemledel'českom termine. Novye lingvističeskie dannye o proishoždenii zemledelija." Vestnik Drevnej Istorii 4, 97-106. 
MilitaRev Aleksandr Jur'evič. 1984. "Sovremennoe sravnitel'no-istoričeskoe afrazijskoe jazykoznanie: čto ono možet dat' istoričeskoj nauke?" In: Lingvističeskaja rekonstrukcija i drevnejšaja istorija Vostoka. Čast' 3. Moskva: Nauka, 3-26.

MilitaRev Aleksandr Jur'evič. 1989. "Ešče raz o proishoždenii zemledelija po dannym praafrazijskoj (prasemitohamitskoj) lingvističeskoj rekonstrukcii." Vestnik Drevnej Istorii 1, 128-131.

Militarev Aleksandr Jur'evič. 2005a. "Once More About Glottochronology and the Comparative Method: the Omotic-Afrasian Case.” In: Orientalia et Classica. Trudy Instituta vostočnyh kul 'tur i antičnosti. Vypusk VI. Moskva: Rossijskij Gosudarstvennyj Gumanitarnyj Universitet, 339-408.

Militarev Aleksandr Jur'evič. 2005b. "Towards the Genetic Affiliation of Ongota, a Nearly-Extinct Language of Ethiopia.” I. Babel und Bibel 2, 567-607.

Militarev Aleksandr Jur'evič, Pejros Il'ja I., Šnirel'man V.A. 1988. "Metodičeskie problemy lingvoarheologičeskih rekonstrukcij étnogeneza." Sovetskaja Étnografija 4, 24-38.

Militarev Aleksandr Jur'evič, Šnirel'man V.A. 1984. 'K probleme lokalizacii drevnejših afrazijcev (opyt lingvo-arheologičeskoj rekonstrukcii)." In: Lingvističeskaja rekonstrukcija i drevnejšaja istorija Vostoka. Tezisy i doklady konferencii. Čast' 2. Lingvističeskaja i istoričeskaja rekonstrukcii (problemy interdisciplinarnyh issledovanij). Moskva: Nauka, 35-53.

Mukarovsky H.G. (ed.). 1990. Proceedings of the Fifth International Hamito-Semitic Congress. Band 1. Wien: Afro-Pub.

ND = Dolgopolsky Aharon. Nostratic Dictionary. Published by the MacDonald Institute of Archaeological Research in Cambridge at http://www.dspace.cam.ac.uk/handle/1810/196512.

NetTing Robert M. 1967. Kofyar Vocabulary. MS.

Newman Paul. 1974. The Kanakuru Language. Leeds: The Institute of Modern English Language Studies, University of Leeds in association with The West African Linguistic Society.

ОнотіNA N.V., Uspenskis B.A. (eds.). 1972. Problemy afrikanskogo jazykoznanija. Tipologija, komparativistika, opisanie jazykov. Moskva: Nauka.

Orel Vladimir Émmanuilovič, Stolbova Ol'ga Valer'evna. 1990. "K rekonstrukcii praafrazijskogo vokalizma." 3-4. Voprosy Jazykoznanija 2, 75-90.

Ormsiy G. "Notes on the Angass Language." Journal of the Royal African Society 12 (1912-1913), 421-424 \& 13 (1913-1914), 54-61, 204-210, 313-315.

Pearce Mary. 1998-1999. "Consonant and Tone in Kera (Chadic)." Journal of West African Languages 27(1), $33-70$.

PorhomovskiJ V.Ja. (ed.). 1987. Afrikanskoe istoričeskoe jazykoznanie. Problemy rekonstrukcii. Moskva: Nauka, 30-268.

Prasse Karl-Gustav, Alojaly Ghubeïd, Mohamed Ghabdouane. 2003. Dictionnaire touareg-français (Niger). Copenhagen: Museum Tusculanum Press, University of Copenhagen.

PT $=$ SETHE Kurt. 1980, 1910. Die altägyptischen Pyramidentexte. I-II. Leipzig: J.C. Hinrichs'sche Buchhandlung.

ReInIsch Leo. 1902. Die Somali-Sprache. II. Wörterbuch. Wien: Alfred Hölder Verlag.

Renisio A. 1932. Étude sur les dialectes berbères des Beni Iznassen, du Rif et des Senhaja de Sraïr. Grammaire, textes et lexique. Paris: Éditions Ernest Leroux.

Roper E.-M. 1928. Tu Bedawie. An Elementary Handbook for the Use of Sudan Government Officials. Hertford: Stephen Austin \& Sons.

SD = Beeston A.F.L., Ghul M. A., Müller W.W., Ryckmans, J. 1982. Sabaic Dictionary (English-French-Arabic). Dictionnaire sabéen (anglais-français-arabe). Louvain-la-Neuve, Beyrouth: Peeters, Librairie du Liban.

SED I = Kogan Leonid, Militarev Aleksandr (with assistance of Anna Belova, Anatolij Kovalev, Adel NemiRovskaja, Denis Nosnitsyn). 2000. Semitic Etymological Dictionary. Vol. I. Anatomy of Man and Animals. Münster: Ugarit-Verlag.

Segert S., Bodrogligeti A.J.E. (eds.). 1983. Ethiopian Studies Dedicated to Wolf Leslau. Wiesbaden: Otto Harrassowitz.

SHevoroshrin V. (ed.). 1989. Reconstructing Languages and Cultures. Bochum: Brockmeyer.

SIEBERT Ralph. 1994. "Languages of the Abbaya/Chamo Area - Report Part I (with Notes on Koorete by L. Hoeft)." Survey of Little-Known Languages of Ethiopia (S.L.L.E.) Reports 21, 1-24.

Simeone-Senelle Marie-Claude, Lonnet Antoine. 1991. 'Lexique soqotri: les noms des parties du corps.' In: Kaye 1991: 1443-1487. 
SiRLINGer E. 1937. Dictionary of the Goemay Language. Jos, Nigeria: Prefecture Apostolic of Jos.

SISAJa I = D'Jakonov Igor' Mihajlovič, Belova Anna Grigor'evna, Četveruhin Aleksandr S., Militarev Aleksandr Jur'evič, Porномоvsкis Viktor Jakovlevič, Stolbova Ol'ga Valer'evna. 1981. "Sravnitel'no-istoričeskij slovar' afrazijskih jazykov. Vypusk 1. p-p-b-f." Pis'mennye pamjatniki i problemy istorii kul tury narodov Vostoka. XV godičnaja naučnaja sessija Leningradskogo Otdelenija Instituta Vostokovedenija Akademii Nauk SSSR. Moskva: Nauka, 3-127.

SISAJa II = D'Jakonov Igor' Mihajlovič, Belova Anna Grigor'evna, Militarev Aleksandr Jur'evič, PorhomovskiJ Viktor Jakovlevič, Stolbova Ol'ga Valer'evna. 1982. "Sravnitel'no-istoričeskij slovar' afrazijskih jazykov. Vypusk 2. t-t-d." Pis'mennye pamjatniki i problemy istorii kul 'tury narodov Vostoka. XVI godičnaja naučnaja sessija Leningradskogo Otdelenija Instituta Vostokovedenija Akademii Nauk SSSR. Moskva: Nauka, 3-93.

SISAJa III = D'Jakonov Igor' Mihajlovič, Belova Anna Grigor'evna, Militarev Aleksandr Jur'evič, PorhoMOvskiJ Viktor Jakovlevič, StolBova Ol'ga Valer'evna. 1986. "Sravnitel'no-istoričeskij slovar' afrazijskih

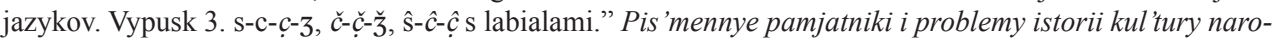
dov Vostoka. XVI godičnaja naučnaja sessija Leningradskogo Otdelenija Instituta Vostokovedenija Akademii Nauk SSSR. Moskva: Nauka, 3-46.

Stolbova Ol'ga Valer'evna. 1987. "Sravnitel'no-istoričeskaja fonetika i slovar' zapadnočadskih jazykov." In: PorhomovskiJ 1987: 30-268.

Stolbova Ol'ga Valer'evna. 1996. Studies in Chadic Comparative Phonology. Moscow: "Diaphragma" Publishers.

Stolbova Ol'ga Valer'evna. 2005. Chadic Lexical Database. Issue I. L, N, NY, R. Kaluga: Poligrafiya.

Stroomer Harry. 1995. A Grammar of Boraana Oromo (Kenya). Phonology, Morphology, Vocabularies. Köln: Buske.

TAddese B. (ed.). 1988. Proceedings of the Eighth International Conference of Ethiopian Studies, University of Addis Ababa, 1984. Vol. 1. Addis Ababa: Institute of Ethiopian Studies.

TAKÁCS, Gábor. 1997. "Review of Orel V. É. \& Stolbova O. V.: Hamito-Semitic Etymological Dictionary: Materials for a Reconstruction.” Journal of Cuneiform Studies 49, 108-117.

TAKÁCS Gábor. 2000. "Proto-Afro-Asiatic Origin of 'Gum'?" Bulletin of the School of Oriental and African Studies 63(1), 96-99.

TAKÁCs Gábor. 2002. "Lexica Afroasiatica I.' Afrikanistische Arbeitspapiere 67, 103-151.

TAKÁCs Gábor. 2004a. Comparative Dictionary of the Angas-Sura Languages. Berlin: Dietrich Reimer Verlag.

TAKÁcs Gábor (ed.). 2004b. Egyptian and Semito-Hamitic (Afro-Asiatic) Studies in Memoriam Werner Vycichl. Leiden: E. J. Brill.

Tosco Mauro. 1991. A Grammatical Sketch of Dahalo. Hamburg: Helmut Buske Verlag.

Uspenskis B.A. (ed.). 1966. Jazyki Afriki. Voprosy struktury, istorii i tipologii. Moskva: Nauka.

Vergote Jozef. 1945. Phonétique historique de l'égyptien. Paris: Le Muséon.

$\mathrm{Wb}=$ ERman Adolf, Grapow Hermann. 1957-1971. Wörterbuch der ägyptischen Sprache. I-V. ${ }^{2}$ Berlin: Akademie-Verlag. 